\title{
LIPID PEROXIDATION AND DNA FRAGMENTATION IN FRESH AND CRYOPRESERVED SPERMATOZOA OF MEN AT DIFFERENT SPERMATOGENESIS STATE
}

\author{
T. O. YURCHUK ${ }^{\bowtie}$, O. V. PAVLOVICH, G. O. GAPON, \\ A. Y. PUGOVKIN, M. P. PETRUSHKO \\ Institute for Problems of Cryobiology and Cryomedicine, National Academy of Sciences \\ of Ukraine, Department of Cryobiology of Reproductive System, Kharkiv; \\ 凶e-mail: taisiya.yur@gmail.com
}

Received: 11 July 2021; Accepted: 17 May 2021

Cryopreservation of spermatozoa is widely used in the treatment of infertility by assisted reproductive technologies. However, the cryopreservation causes an oxidative stress which can induce pathological changes in the male gametes. The aim of the research was to evaluate lipid peroxidation (LPO) and DNA fragmentation as well as correlation between these parameters in the fresh and cryopreserved spermatozoa of men with normozoospermia or oligoasthenoteratozoospermia (OAT) and spermatozoa derived from the epididymis of men with azoospermia. The level of malondialdehyde (MDA) in a TBA test, superoxide dismutase (SOD) activity and total antioxidant activity (AOA) were assessed. DNA integrity was estimated by acridine orange staining technique. It was shown that MDA level and SOD activity were significantly higher in the fresh spermatozoa of oligoasthenoteratozoospermic group compared with the fresh spermatozoa of normozoospermic group. After cryopreservation the MDA level increased in all groups and was the highest in OAT group where the greatest AOA decline was detected. DNA fragmentation frequency was 2.6 and 4.1 times higher in the fresh and cryopreserved OAT spermatozoa respectively as compared with the fresh normozoospermic ones (7.2\%). DNA fragmentation was found to be the lowest in the fresh (6.2\%) and cryopreserved (5.8\%) epididymal spermatozoa. After cryopreservation SOD activity in epididymal spermatozoa was lower than in normozoaspermic. In spermatozoa of the studied groups the MDA level positively correlated with DNA fragmentation (0.79 Pearson's correlation coefficient) both before and after cryopreservation. It is suggested that due to the detected low DNA fragmentation and LPO level in epididymal spermatozoa their use could be an alternative approach for infertility treatment by assisted reproductive technologies.

K e y w o r d s: spermatozoa, cryopreservation, MDA, SOD, antioxidant activity lipid peroxidation, DNA fragmentation, different spermatogenesis state.

$\mathrm{T}$ here is no doubt that reactive oxygen species (ROS) play an important role in the functioning of different cell types, including male gametes [1, 2]. Production of ROS is a mandatory step of the natural processes such as posttesticular spermatozoa maturation, apoptosis, in capacitation, hyperactivation, acrosome reaction, and spermatozoa-oocyte fusion. On the other hand, an access ROS level can indicate pathological processes. Thus, ROS influence the seminal parameters such as motility, count, volume, activity [3]. ROS implement their effects on spermatozoa functional state by oxidizing the proteins, inducing damage to nucleic acids and peroxidation of lipids (LPO) [4-6]. Clinical observations are increasingly showing the relationship between the spermatozoa LPO processes and male infertility as well as play an important role in oocyte fertilization outcomes [7, 8]. Since ROS can cause DNA fragmentation and LPO in human spermatozoa, it is important to investigate the relationship of these processes in men with different spermatogenesis state [9]. Additionally, spermatozoa cryopreser-

(C) 2021 Yurchuk T. O. et al. This is an open-access article distributed under the terms of the Creative Commons Attribution License, which permits unrestricted use, distribution, and reproduction in any medium, provided the original author and source are credited. 
vation can induce injury by ice formation and osmotic stress following reducing membrane fluidity and causing excessive production of endogenous and exogenous ROS [10, 11].

Thus, the aim of the study was to investigate the level of lipid peroxidation and DNA fragmentation in fresh and cryopreserved spermatozoa of men with different spermatogenesis state, as well as to establish a correlation between these parameters.

\section{Materials and Methods}

Ejaculated sperm samples obtained from the patients, who underwent infertility treatment from 2017 to 2019, were analyzed. The study included 138 patients (mean age of $32 \pm 3.4$ ). The study was approved by the Biomedical Ethical Committee of the Institute for Problems of Cryobiology and Cryomedicine of the National Academy of Sciences of Ukraine, in line with the Law of Ukraine "On Personal Data Protection” (2010). Informed consents were obtained from all the participants in line with the WHO regulation [12].

The following study groups were identified: the spermatozoa retrieved from the ejaculates of normozoospermic men (group 1), spermatozoa retrieved from the ejaculates from men with oligoasthenoteratozoospermia (OAT) (group 2), and spermatozoa retrieved by microsurgical or percutaneous epididymal aspiration in men with azoospermia (group 3).

The active motile sperm fraction was isolated in a density gradient Sperm Grade (LifeGlobal, USA) [13]. A two-stage method was used for spermatozoa cryopreservation. Active motile sperm fraction was mixed in $1: 1$ ratio with cryoprotective medium containing 10\% glycerol (Sigma Pharmaceutical, Buchs, Switzerland), 20\% human serum albumin (LifeGlobal, USA) based on Global total for fertilization medium (LifeGlobal, USA) in $1 \mathrm{ml}$ cryovials. After $10 \mathrm{~min}$ of exposure, the cryovials were placed $10 \mathrm{~cm}$ above the liquid nitrogen mirror level for $15 \mathrm{~min}$ and then plunged into the liquid nitrogen, where they were stored during 1-3 months. Samples were warmed in a water bath at $40^{\circ} \mathrm{C}$ until complete disappearance of the solid phase. The cell suspension was centrifuged and the supernatant was removed. The culture medium of $0.1 \mathrm{ml}$ was added to the precipitate.

The concentration of MDA was determined by the intensity of the color formed during the reaction of MDA and thiobarbituric acid (TBA), which takes place in an acidic environment at high temperature [14]. The superoxide dismutase (SOD) activity was determined by the reduction of the dye nitrosine tetrazolium and expressed in conventional units: for 1 conventional unit was $50 \%$ of inhibited redox reaction [15]. Optical density was measured using a Shimadzu QV-50 spectrophotometer (Japan). Antioxidant activity (AOA) was determined in a model system of suspension of yolk lipoproteins [16]. AOA was expressed as a percentage from inhibition of $50 \%$ LPO in the model system compared to the classical antioxidant ionol.

The DNA fragmentation rate of spermatozoa was measured using acridine orange (AO) staining and fluorescent microscopy [17]. AO fluoresces green when it binds to native DNA and it does red when it binds to the fragmented DNA (Fig. 1). In each sample, the number of red and green fluorescence cells were counted among 100 cells and represented in percentage.

Statistica 6.0 was used for the results processing. When comparing the samples, the MannWhitney U-test was used at a significance level of $P \leq 0.05$.

\section{Results and Discussion}

At the first stage, the LPO processes are characterized by formation of primary (diene, triene, tetraene conjugates) and secondary products. One such compound is MDA, an intermediate product

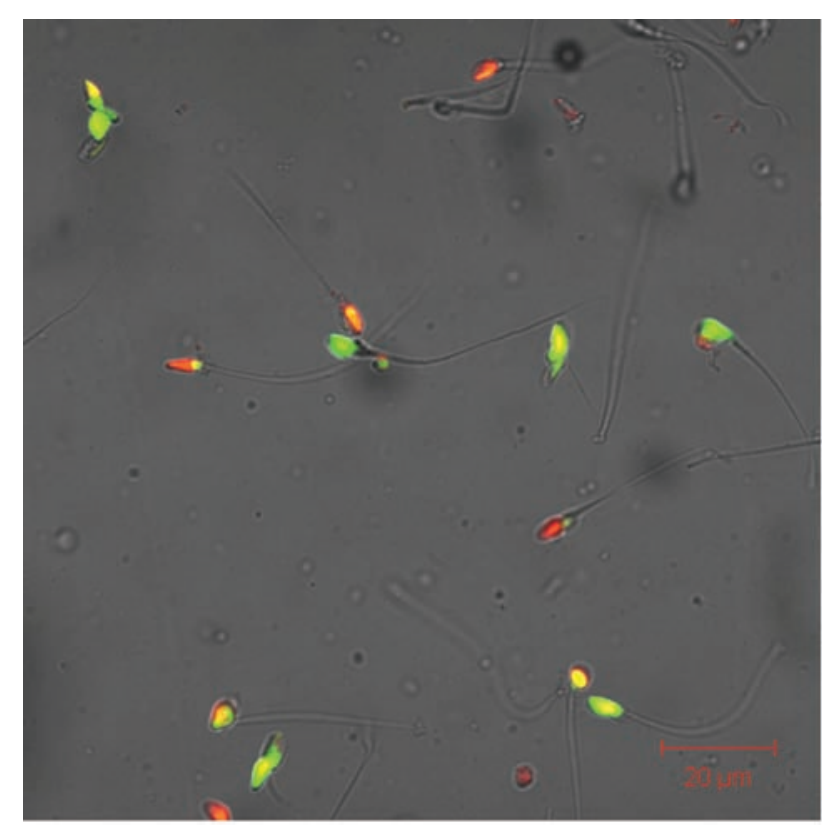

Fig. 1. Acridine orange staining of human spermatozoa; cells with red fluorescence have fragmented $D N A$, cells with green fluorescence have native DNA 
of enzymatic arachidonic acid oxidation and the final product of oxidative degradation of lipids. MDA refers to the products that interact specifically with TBA being a marker of oxidative stress.

It has been established that there is a quantitative relationship between LPO processes and MDA concentration. When studying the oxidative state and antioxidant systems in spermatozoa of men with different spermatogenesis state, it was found that the level of MDA was significantly higher in group 2 compared with this index in group 1 (Table 1). The level of MDA in sperm of group 3 was comparable to group 1 . The level of SOD in group 2 was significantly higher than in group 1 . This fact can be considered as a compensatory response to the excess ROS level in OAT spermatozoa. However, AOA levels in OAT spermatozoa tended to decrease compared with normozoospermic and epididymal spermatozoa.

The study of the DNA fragmentation rate showed that in group 2, this indicator was the highest and amounted to $19.7 \pm 7.73 \%$. There were no significant differences in groups 1 and 3.

After cryopreservation, the MDA concentration increased and was the highest in group 2 (Table 2). The accumulation of peroxidation products can lead to appearance of peculiar membrane pores by increasing the hydrophilic hydrocarbon tails content, as well as to increase its stiffness by reducing the content of unsaturated fatty acids and thereby affecting the membrane permeability [18]. Thus, the membranes of OAT spermatozoa undergo significant structural changes, which may affect their cryoresistance.

The activity of SOD in cryopreserved spermatozoa was significantly higher in group 2 compared with group 1 . In group 3 , there was a decrease in this index by 1.9 times relative to normal spermatozoa.

Table 1. Level of MDA, SOD, AOA in fresh human spermatozoa of men with different states of spermatogenesis

\begin{tabular}{l|c|c|c}
\hline Groups & $\begin{array}{c}\text { MDA, } \\
\mu \mathrm{M} / 10^{6} \\
\text { sperm }\end{array}$ & SOD, c. u. & AOA, \% \\
\hline Group 1 & $8.0 \pm 0.6$ & $4.5 \pm 0.3$ & $8.5 \pm 0.7$ \\
Group 2 & $9.7 \pm 1.1^{*}$ & $6.3 \pm 0.4^{*}$ & $7.3 \pm 0.8$ \\
Group 3 & $8.2 \pm 0.6$ & $3.2 \pm 0.3^{*}$ & $8.0 \pm 0.9$ \\
\hline
\end{tabular}

Note: * difference is significant compared to corresponding index in group $1(P<0.05)$

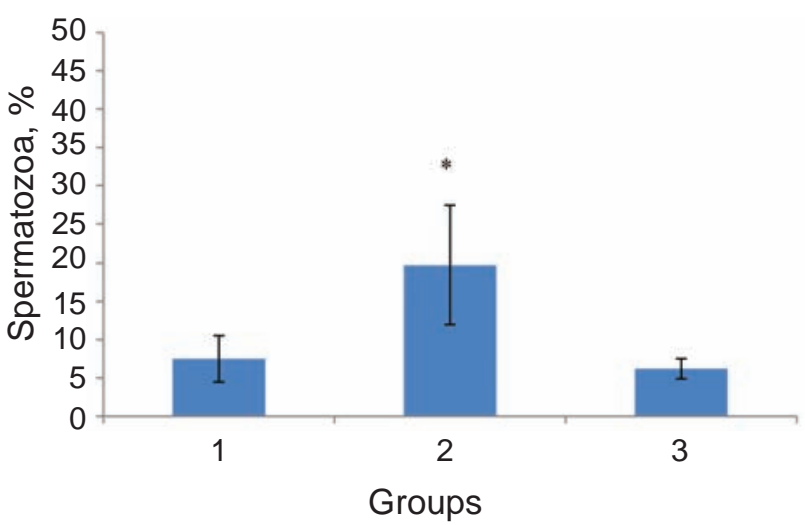

Fig. 2. DNA fragmentation rate in cryopreserved human spermatozoa of men with different states of spermatogenesis, *difference is significant compared to the corresponding index in group 1 $(P<0.05)$

AOA decreased 5.4 times in group 2 cryopreserved spermatozoa compared with group 1 . There was also a tendency to decrease in group 3 spermatozoa compared with group 1 .

DNA fragmentation rate in group 2 cryopreserved spermatozoa increased 4.1 times compared with group 1 and was the lowest in group 3 (5.8 \pm 1.3$) \%$ (Fig 2).

The values of MDA concentrations in the studied groups both before and after cryopreservation positively correlated with DNA fragmentation rate (Pearson's correlation coefficient was 0.79 and was significant at $95 \%$ confidence interval). There is also a negative correlation between SOD and DNA fragmentation in spermatozoa in the studied groups (Pearson's correlation coefficient was 0.77).

It should be noted that the presence of positive or negative correlation between the indices does not indicate a causal relationship between them. A si-

Table 2. Level of MDA, SOD, AOA in cryopreserved human spermatozoa of men with different states of spermatogenesis

\begin{tabular}{l|c|c|c}
\hline Groups & $\begin{array}{c}\text { MDA, } \\
\mu \mathrm{M} / 10^{6} \\
\text { sperm }\end{array}$ & SOD, c. u. & AOA, \% \\
\hline Group 1 & $9.8 \pm 0.8$ & $3.3 \pm 0.3$ & $6.5 \pm 0.6$ \\
Group 2 & $12.8 \pm 1.2^{*}$ & $4.3 \pm 0.3^{*}$ & $1.2 \pm 0.1^{*}$ \\
Group 3 & $10.2 \pm 0.9$ & $2.3 \pm 0.2^{*}$ & $5.8 \pm 0.4$ \\
\hline
\end{tabular}

Note: * difference is significant compared to the corresponding index in group $1(P<0.05)$ 
multaneous variation is likely due to the influence of another variable and the mechanism or system connections of this phenomenon can be complicated. We assume that the increase in MDA in spermatozoa is associated with a higher level of DNA fragmentation and may indicate apoptosis activation. MDA formation occurs during the cleavage of lipid hydroperoxides induced by oxidative stress [19]. Also, it could cause the destruction of covalent complexes with amino groups of proteins, induces specific nuclease activation leading to DNA fragmentation. The negative impact of cryopreservation increases the ROS effects.

The detected elevated level of LPO products in spermatozoa of OAT men indicates the negative effects of activation of peroxide processes in cells. Normally, the processes of ROS peroxidation, in particular LPO, are maintained at a stationary level due to the antioxidant system. The accumulation of LPO products can be an important factor, leading to disordered integrity of the spermatozoa membrane after freeze-warming [20].

The results of the antioxidant status study indicate a deficiency of antioxidant protection in both fresh and cryopreserved OAT spermatozoa in comparison with normozoospermic and epididymal spermatozoa. As noted above, an increase in SOD level was observed in OAT spermatozoa probably due to the compensatory response to the ROS increasing. However, after cryopreservation, the SOD activity was lower than in fresh OAT spermatozoa despite the increased LPO level and DNA fragmentation rate. Thus, cryopreservation of gametes from OAT men leads to a decrease in SOD activity. And since the SOD addition to spermatozoa can decrease the DNA fragmentation rate, it may be promising for using for OAT spermatozoa cryopreservation in order to increase their fertilization capacity [21]. It is well known that high spermatozoa DNA fragmentation rate is one of the causes of male infertility, and in case of high index of this parameter no patient has reached pregnancy when underwent infertility treatment by assisted reproductive technologies (ART) [22]. An alternative approach may be the use of epididymal spermatozoa for infertility treatment by ART due to the much lower DNA fragmentation rate and LPO level.

Conclusions. The level of MDA and SOD was significantly lower in normozoospermic spermatozoa than in OAT. After cryopreservation, the concentrations of MDA and SOD were increased while
AOA was decreased in OAT spermatozoa. DNA fragmentation rate in fresh OAT spermatozoa was 2.6 times higher than normozoospermic and increased 4.1 times after cryopreservation. Epididymal spermatozoa had the lowest DNA fragmentation rate $(6.2 \pm 1.3) \%$. It was found that DNA fragmentation of OAT sperm is significantly higher than in epididymal after cryopreservation (19.7 \pm 7.73 vs $5.8 \pm 1.3) \%$. A correlation between the MDA level and DNA fragmentation rate $(r=0.79, P<0.05)$ was found in all the studied groups before and after cryopreservation.

Conflict of interest. The authors have completed the Unified Conflicts of Interest form at http:// ukrbiochemjournal.org/wp-content/uploads/2018/12/ coi_disclosure.pdf and declare no conflict of interest.

Acknowledgments. The study was supported by the budget topic of the Ministry of Education of Ukraine 0120U100378 "Assessment of DNA fragmentation degree of spermatogenic cells at different stages of differentiation as a mandatory component of the technology of their cryopreservation”. Applied scientific research" (2020-2022 academic years).

ПЕРОКСИДНЕ ОКИСЛЕННЯ
ЛІПІДІ ТА ФРАГМЕНТАЦІЯ
ДНК У НАТИВНИХ
I КРІОКОНСЕРВОВАНИХ
СПЕРМАТОЗОЇДАХ ЧОЛОВІКІВ
ІЗ РІЗНИМ СТАНОМ
СПЕРМАТОГЕНЕЗУ
Т. О. Юрчук ${ }^{凶}$ О. В. Павлович, Г. О. Гапон, А. Ю. Пуговкін, М. П. Петрушко

Інститут проблем кріобіології і кріомедицини НАН України, відділ кріобіології системи репродукції, Харків; 凶e-mail: taisiya.yur@gmail.com

Кріоконсервування сперматозоїдів широко використовується для лікування безпліддя за допомогою репродуктивних технологій. Однак процес кріоконсервування спричинює оксидативний стрес, що може індукувати патологічні зміни в чоловічих гаметах. Метою дослідження було оцінити пероксидне окислення ліпідів (ПОЛ) та фрагментацію ДНК, а також кореляцію між цими показниками у щойно одержаних та кріоконсервованих сперматозоїдах чоловіків із нормозооспермією, олігоастенотератозооспермією (ОАТ) та 
сперматозоїдах із епідидимусу за азооспермії. Визначали рівень малонового діальдегіду (МДА), активність супероксиддисмутази (СОД) та загальну антиоксидантну активність (АОА) сперматозоїдів. Показано, що рівень МДА та СОД був значно вищим у щойно одержаних сперматозоїдах групи ОАТ порівняно 3 нормозооспермічними. Після кріоконсервування рівень МДА підвищився в сперматозоїдах усіх груп, найвищим був у групі ОАТ, де виявлено найбільше зниження антиоксидантної активності. Частота фрагментації ДНК у сперматозоїдах групи ОАТ до та після кріоконсервування була відповідно у 2,6 та у 4,1 раза вищою порівняно з показником у нативних нормозооспермічних сперматозоїдах (7,2\%). Частота фрагментації ДНК була найнижчою в епідидимальних сперматозоїдах як до $(6,2 \%)$, так і після $(5,8 \%)$ кріоконсервування. Рівень СОД у епідидимальних сперматозоїдах після кріоконсервування був нижчим, ніж у нормозооспермічних. Виявлено позитивну кореляцію між рівнем МДА та частотою фрагментації ДНК (коефіцієнт кореляції Пірсона - 0,79) у сперматозоїдах усіх груп до та після кріоконсервування. Дійшли висновку, що порівняно низький рівень ПОЛ та фрагментації ДНК в епідидимальних сперматозоїдах робить можливим їх використання для терапії безпліддя.

К л ю ч о в і с л о в а: сперматозоїди, кріоконсервування, МДА, СОД, антиоксидантна активність, пероксидне окислення ліпідів, фрагментація ДНК, різний стан сперматогенезу.

\section{References}

1. Homa ST, Vessey W, Perez-Miranda A, Riyait T, Agarwal A. Reactive Oxygen Species (ROS) in human semen: determination of a reference range. J Assist Reprod Genet. 2015; 32(5): 757764.

2. Lushchak VI. Free radicals, reactive oxygen species, oxidative stresses and their classifications. Ukr Biochem J. 2015; 87(6): 1118.

3. Layali I, Tahmasbpour E, Joulaei M, Jorsaraei SG, Farzanegi P. Total antioxidant capacity and lipid peroxidation in semen of patient with hyperviscosity. Cell J. 2015; 16(4): 554-559.
4. Chabory E, Damon C, Lenoir A, HenryBerger J, Vernet P, Cadet R, Saez F, Drevet JR. Mammalian glutathione peroxidases control acquisition and maintenance of spermatozoa integrity. J Anim Sci. 2010; 88(4): 1321-1331.

5. Moazamian R, Polhemus A, Connaughton H, Fraser B, Whiting S, Gharagozloo P, Aitken RJ. Oxidative stress and human spermatozoa: diagnostic and functional significance of aldehydes generated as a result of lipid peroxidation. Mol Hum Reprod. 2015; 21(6): 502-515.

6. Len JS, Koh WSD, Tan SX. The roles of reactive oxygen species and antioxidants in cryopreservation. Biosci Rep. 2019; 39(8): BSR20191601.

7. Dorostghoal M, Kazeminejad SR, Shahbazian N, Pourmehdi M, Jabbari A. Oxidative stress status and sperm DNA fragmentation in fertile and infertile men. Andrologia. 2017; 49(10): e12762.

8. Petrushko MP, Pinyaev VI, Pravdina SS, Podufaly VV, Chub NN. Genetic aspects of male infertility. Spad metabolic illness: abstract add. IV International Congress, Kharkiv, 2010. Ultrasound perinatal diagnosis. 2010; 27-28: 151. (In Russian).

9. Thomson LK, Fleming SD, Aitken RJ, De Iuliis GN, Zieschang JA, Clark AM. Cryopreservation-induced human sperm DNA damage is predominantly mediated by oxidative stress rather than apoptosis. Hum Reprod. 2009; 24(9): 2061-2070.

10. Abdillah DA, Setyawan EMN, Oh HJ, Ra K, Lee SH, Kim MJ, Lee BC. Iodixanol supplementation during sperm cryopreservation improves protamine level and reduces reactive oxygen species of canine sperm. $J$ Vet Sci. 2019; 20(1): 79-86.

11. Kopeika EF, Petrushko MP, Piniaiev VI, Yurchuk TO, Pavlovich OV, Mikson KB, Butskyi KI, Hapon HO, Puhovkin AYu. Cryopreservation of reproductive cells and embryos of laboratory, agricultural and wild animals. Probl Cryobiol Cryomed. 2019; 29(1): 003-018.

12. WHO laboratory manual for the Examination and processing of human semen fifth edition. World Health Organization, Department of Reproductive Health and Research. 2010: 287. 
13. Krausz C, West K, Buckingham D, Aitken RJ. Development of a technique for monitoring the contamination of human semen samples with leukocytes. Fertil Steril. 1992; 57(6): 1317-1325.

14. Agarwal A, Ikemoto I, Loughlin KR. Relationship of sperm parameters with levels of reactive oxygen species in semen specimens. $J$ Urol. 1994; 152(1): 107-110.

15. Nissen HP, Kreysel HW. Superoxide dismutase in human semen. Klin Wochenschr. 1983; 61(1): 63-65.

16. Klebanov GI, Babenkova IV, Teselkin YuO, Komarov OS, Vladimirov YuA. Evaluation of the antioxidative activity of blood plasma using yolk lipoproteins. Lab Delo. 1988; (5): 59-62. (In Russian).

17. Dashtestani F, Ghourchian H, Najafi A. Albumin coated copper-cysteine nanozyme for reducing oxidative stress induced during sperm cryopreservation. Bioorg Chem. 2018; 80: 621630.

18. Varghese AC, Fischer-Hammadeh C, Hammadeh ME. Acridine Orange Test for Assessment of Human Sperm DNA Integrity. In: Zini A., Agarwal A. (eds.) Sperm Chromatin. NY: Springer, New York, 2011. P. 189-199.

19. Chyra-Jach D, Kaletka Z, Dobrakowski M, Machoń-Grecka A, Kasperczyk S, Birkner E, Kasperczyk A. The Associations between Infertility and Antioxidants, Proinflammatory Cytokines, and Chemokines. Oxid Med Cell Longev. 2018; 2018: 8354747.

20. Sandro C, Verza JrS. Relationship of in vitro acrosome Reaction to Sperm Function: An Update. Open Reprod Sci J. 2011; 3(1): 72-84.

21. Negri L, Benaglia R, Monti E, Morenghi E, Pizzocaro A, Levi Setti PE. Effect of superoxide dismutase supplementation on sperm DNA fragmentation. Arch Ital Urol Androl. 2017; 89(3): 212-218.

22. Al Omrani B, Al Eisa N, Javed M, Al Ghedan M, Al Matrafi H, Al Sufyan H. Associations of sperm DNA fragmentation with lifestyle factors and semen parameters of Saudi men and its impact on ICSI outcome. Reprod Biol Endocrinol. 2018; 16(1): 49. 